\title{
The effect of drying treatment to metabolite profile and cytotoxic potential of Rhizophora apiculata leaves
}

\author{
MADA TRIANDALA SIBERO ${ }^{1,2, \bullet}$, ANGGUN PUSPITARINI SISWANTO ${ }^{2,3}$, RUDHI PRIBADI $^{1}$, AGUS SABDONO $^{1}$, \\ OCKY KARNA RADJASA ${ }^{1}$, AGUS TRIANTO ${ }^{1}$, EVAN HANSEL FREDERICK ${ }^{1,2}$, ALDI PRATAMA WIJAYA ${ }^{1,2}$, \\ DWI HARYANTI ${ }^{1}$, DESY WULAN TRININGSIH ${ }^{4}$, SASTRA JENDRA HAYUNINGRAT ${ }^{1,2}$, \\ YASUHIRO IGARASHI ${ }^{4}$ \\ ${ }^{1}$ Department of Marine Science, Faculty of Fisheries and Marine Science, Universitas Diponegoro. Jl. Prof. H. Soedarto, S.H., Tembalang, Semarang \\ 50275, Central Java, Indonesia. Tel.: +62-24-7474698, Fax.: +62-24-7474698, `email: madatriandalasibero@lecturer.undip.ac.id \\ ${ }^{2}$ Laboratory of Tropical Bioprospecting and Biomedicine Studies, Integrated Laboratory, Universitas Diponegoro. Jl. Prof. H. Soedarto, S.H., Tembalang, \\ Semarang 50275, Central Java, Indonesia \\ ${ }^{3}$ Chemical Engineering, Vocational School, Universitas Diponegoro. Jl. Prof. H. Soedarto, S.H., Tembalang, Semarang 50275, Central Java, Indonesia \\ ${ }^{4}$ Biotechnology Research Center, Department of Biotechnology, Toyama Prefectural University. 5180 Kurokawa, Imizu-shi, Toyama 939-0398, Japan
}

Manuscript received: 17 March 2020. Revision accepted: 24 April 2020.

\begin{abstract}
Sibero MT, Siswanto AP, Pribadi R, Sabdono A, Radjasa OK, Trianto A, Frederick EH, Wijaya AP, Haryanti D, Triningsih DW, Hayuningrat SJ, Igarashi Y. 2020. The effect of drying treatment to metabolite profile and cytotoxic potential of Rhizophora apiculata leaves. Biodiversitas 21: 2180-2187. Coastal communities in Indonesia have utilized Rhizophora spp. leaves as a traditional medicine for many years. The previous studies have succeeded in extracting bioactive compounds from this mangrove after drying treatment, but there is a possibility of the compound decomposition or breakdown. This study aimed to determine the effect of drying treatment on the metabolite profile of $R$. apiculata leaves which were taken from mangrove forests in Rembang, Central Java. The effect of pre-drying treatment was examined by comparing the metabolites profiles of fresh, oven-dried, and sun-dried leaves crude extracts. Extraction was carried out using maceration method with agitation (110 r.p.m.) for 24 hours in methanol. The metabolite profile was analyzed using high-performance liquid chromatography (HPLC) with diode array detector (DAD) and thin layer chromatography (TLC), while secondary metabolites were studied by phytochemical test. The phytochemical results showed that there were no differences in metabolites in dried and fresh R. apiculata leaves. Crude extract of fresh and oven-dried gave 10 spots on the TLC, while sun-dried crude extract had 9 spots. The one missing spot $\left(R_{\mathrm{f}}\right.$ value of 0.79$)$ in the sun-dried crude extract might have unstable compounds that are easily degraded or damaged by the sunlight. Moreover, HPLC chromatogram indicated the pre-drying treatment gave alteration to the $R$. apiculata metabolites that only detected at $400 \mathrm{~nm}$. Cytotoxic assay against P388 murine leukemia cell indicated that oven-dried treatment gave the best anticancer activity with IC50 value of $0.0323 \mathrm{mg} / \mathrm{mL}$.
\end{abstract}

Keywords: Bioactive, chromatography, cytotoxic, drying, Rhizophora

\section{INTRODUCTION}

FAO (2005) and Darajati et al. (2016) stated that Indonesia as a maritime country has abundant mangrove genera such as Avicennia, Bruguiera, Ceriops, Excoecaria, Lumnitzera, Rhizophora, Sonneratia, and Xylocarpus. These coastal plants provide sufficient ecological services for its associated organisms. In terms of ecosystem services for humans, mangrove has been used as traditional medicine especially in Asian countries for many years (Tarman et al. 2013; Saranraj and Sujitha 2015; Saranya et al. 2015). Bibi et al. (2019) stated that China, India, Malaysia, Philippines, and Thailand utilized various mangroves to cure diarrhea, vomiting, diabetes, fever, intestinal worm infection, stings from venomous fishes, etc. Furthermore, these medicinal properties in mangrove are influenced by the production of secondary metabolites (Aljaghthmi et al. 2018). The secondary metabolites of mangroves help themselves to adapt to the extreme habitat (Basyuni et al. 2012, 2019).

Local communities in several coastal regions in Indonesia utilize mangrove metabolites for natural dye, paralytic substance for fishing, as well as traditional medicine (Purwanti 2016; Kusmana 2018; Pringgenies et al. 2018). Among all mangrove species, R. apiculata is commonly found in most of Indonesia's mangrove forests. Thus, this species is used as traditional medicine. However, the study of $R$. apiculata as biomedicine is less done rather than $R$. mucronata. Tarman et al. (2013) reported the alkaloid derivatives in the crude extract of $R$. mucronata leaves successfully inhibited diarrhea causative agents. Several studies also reported the effectiveness of $R$. mucronata against plenty of pathogens (Joel and Bhimba 2010; Saranraj and Sujitha 2015; Saranya et al. 2015; Sumardi et al. 2018). Nevertheless, study from other countries showed outstanding antimicrobial and anticancer properties of $R$. apiculata (Seepana et al. 2016; Ramalingam and Rajaram, 2018). Therefore, $R$. mucronata and $R$. apiculata are recognized as a traditional medicinal herb.

As an herbal plant, it is really important to understand the appropriate handling of $R$. apiculata to maintain the bioactive contents to be not degraded. Joel and Bhimba (2010) did a shade drying before extraction of the bioactive 
in the leaves, on the other hand, Sumardi et al. (2018) dried the leaves at $60-75^{\circ} \mathrm{C}$ before extraction. In addition, this mangrove also reported as a potential source of anticancer agents (Diastuti and Warsinah 2010; Palaniyandi et al. 2018). Nonetheless, there is no further study about the effect of the drying treatment on the metabolite profile and its biological activity, especially anticancer. Hence, this study was conducted to understand the impact of different drying treatment on the metabolite profile.

\section{MATERIALS AND METHODS}

\section{General information}

Methanol for extraction was purchased from PT. Brataco Chemicals, Indonesia. Evaporation using rotary evaporator (EYELA N-1001S-W, USA) then dried using vacuum centrifuge (Speed Vac ${ }^{\circledR}$ Plus) SC210A combined with refrigerated vapor trap (RVT 400, Thermo Scientific). Acetonitrile, chloroform, formic acid, and methanol for chromatography analysis were purchased from Wako, Japan. Thin-layer chromatography (TLC) glass plate using silica $60 \quad F_{254}$ base from Merck, Germany. Highperformance liquid chromatography (HPLC) instrument from Agilent 1100 series (Agilent Technologies, USA) with diode array detector (DAD) and column COSMOSIL $3 \mathrm{C}_{18}$-AR-II $(4.6 \mathrm{ID} \times 100 \mathrm{~mm})$ from Nacalai Tesque, Japan.

\section{Sampling}

$R$. apiculata leaves were collected from a mangrove forest in Rembang, Central Java, Indonesia with coordinate $6^{\circ} 41^{\prime} 57.4^{\prime \prime S} 111^{\circ} 23^{\prime} 18.6 " \mathrm{E}$ (Figure 1) and kept in a ziplock plastic bag then brought to the laboratory for further step. Sample was taken in September 2019.

\section{Sample preparation}

Sorting was done to discard the infected, old, and broken leaves. All green and healthy leaves (without any infection symptom) were resized using a mechanical grinder then divided into three groups for drying treatments: fresh (75.5 g), sun-dried (75.5 g), and ovendried at $40{ }^{\circ} \mathrm{C}(75.5 \mathrm{~g})$. Further, samples were extracted using methanol by maceration combined with agitation (110 r.p.m.) at room temperature $\left(27^{\circ} \mathrm{C}\right)$ for 24 h. Samples were separated using cotton to obtain the solvent phase and then concentrated using rotary evaporator at 30-35 $\mathrm{C}$. The crude extracts were dried using cold vacuum centrifuge for $3 \times 24 \mathrm{~h}$ then stored at- $20^{\circ} \mathrm{C}$ to prevent degradation of components.

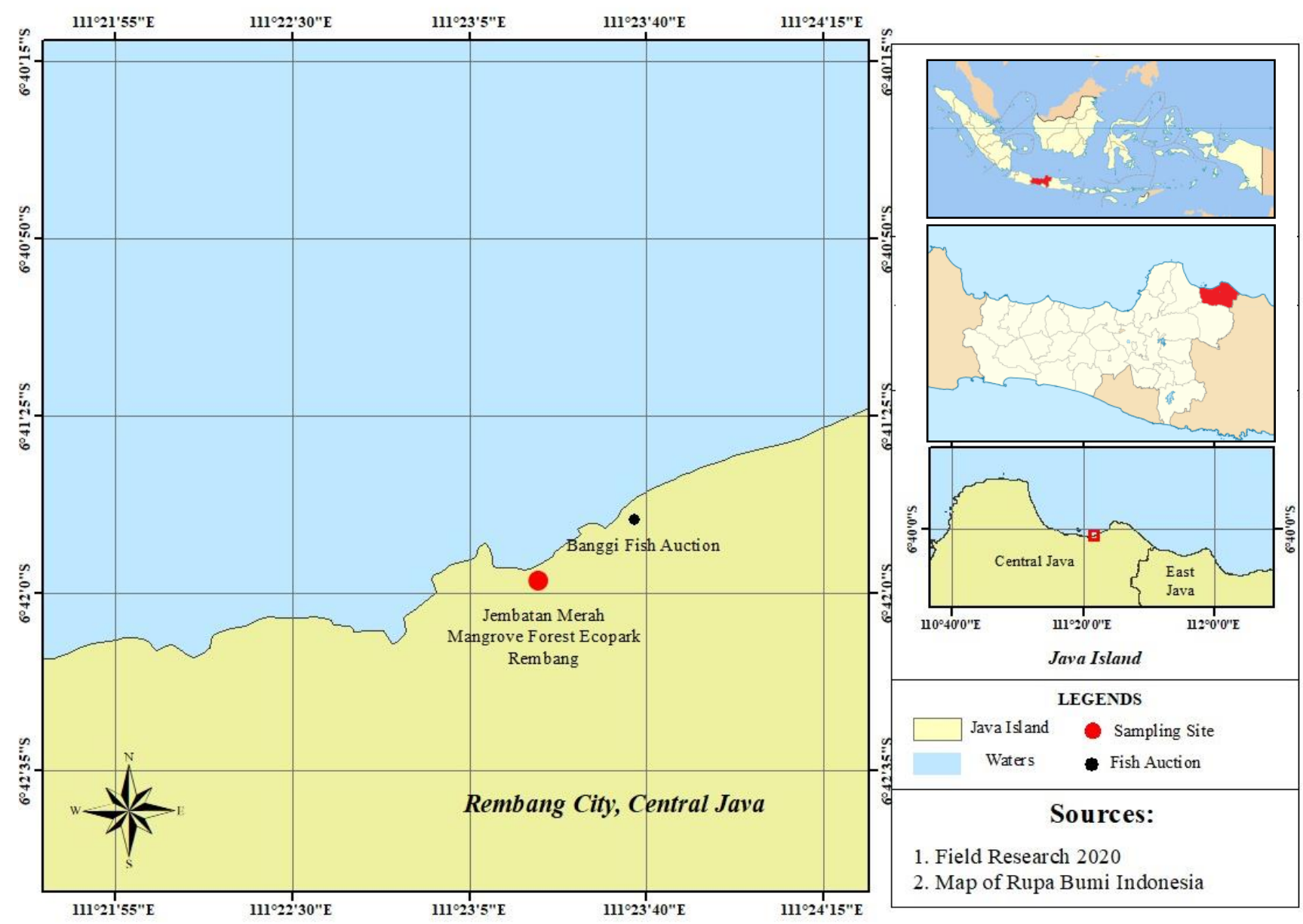

Figure 1. Sampling location in Rembang, Central Java, Indonesia 


\section{Metabolite profiling \\ Phytochemical test}

Phytochemical test was performed for alkaloid, saponin, and steroid according to Sibero et al. (2019) while flavonoid and tannin were referred to Khan et al. (2011).

\section{Thin-layer chromatography (TLC) method}

A TLC glass plate $\mathrm{F}_{254}$ (Merck) was prepared for this analysis. The crude extracts with concentration $4 \mathrm{mg} / \mathrm{mL}$ were dotted onto the TLC plate then run in a TLC chamber. Chloroform (Wako, Japan), methanol (Wako, Japan), and water with ratio 7:3:0.5 (v/v) were prepared as the eluent system. A sulfuric acid (5\%) (Wako, Japan) in 1-butanol (Wako, Japan) was sprayed onto the TLC plate then heated at $60-80{ }^{\circ} \mathrm{C}$ for spot visualization.

\section{High-performance liquid chromatography with diode array detector (HPLC-DAD)}

A total of $100 \mu \mathrm{L}$ sample with concentration $1 \mathrm{mg} / \mathrm{mL}$ was injected into HPLC-DAD for metabolite profiling. Eluent system for this chromatography was acetonitrile (Wako, Japan) and $0.1 \%$ formic acid (Wako, Japan) solution. Metabolite profiling using HPLC was carried out with the following condition: $0-40 \%$ of acetonitrile for 0 $25 \mathrm{~min}, 40-85 \%$ for $25-28 \mathrm{~min}, 85 \%$ for $28-30 \mathrm{~min}$, and $85-90 \%$ for 30-35 min. The flow rate was $1.2 \mathrm{~mL} / \mathrm{min}$, pressure 160 bar with column COSMOSIL $3 \mathrm{C}_{18}$-AR-II $(4.6 \mathrm{ID} \times 100 \mathrm{~mm})$ from Nacalai Tesque.

\section{Cytotoxicity assay}

Cytotoxicity potential of $R$. apiculata leaves was evaluated to inhibit P388 murine leukemia cells according to Sharma et al. (2019). The cells were recultured in RPMI1640 medium containing and HEPES (product no. 18902145) supplemented with $10 \%$ fetal bovine serum, 0.1 $\mathrm{mg} / \mathrm{ml}$ gentamicin sulfate, L-glutamine, and phenol red. The crude extracts were diluted in DMSO with concentration 2 to $2 \times 10-3 \mathrm{mg} / \mathrm{mL}$. Doxorubicin was set as positive control with concentration $1 \times 10-1$ to $1 \times 10-4$ $\mu \mathrm{g} / \mathrm{mL}$, while DMSO as negative control. P388 murine leukemia cells with density 104 cells $/ \mathrm{mL}$ were prepared and added into 96-well round-bottom microtiter plate with volume of $200 \mu \mathrm{L} /$ well while samples and control were added with volume of $1 \mu \mathrm{L} /$ well with 3 repetitions. Plate was homogenized and then incubated for $72 \mathrm{~h}$ at $37{ }^{\circ} \mathrm{C}$ in an atmosphere of $5 \% \mathrm{CO}_{2}$ in air with $100 \%$ humidity. After that, $50 \mu \mathrm{L}$ of XTT was added and incubated for $4 \mathrm{~h}$ to visualize the cell viability. The cell viability was counted using microplate reader at $450 \mathrm{~nm}$. The data was plotted into a linear regression equation with formula $\mathrm{Y}=\mathrm{a}+\mathrm{bX}$ utilized to count the $\mathrm{IC}_{50}$ to understand the cytotoxicity potential (Sharma et al. 2019).

\section{RESULTS AND DISCUSSION}

Mangrove produces bioactive compounds to adapt to their extreme habitat (Joel and Bhimba 2010; Sumardi et al. 2018). The bioactive compound is defined as a chemical substance that gives biological effects on organisms in in vitro and/or in vivo test (Guaadaoui et al. 2014; Dewanjee et al. 2015). Unfortunately, several unstable bioactive compounds are broken down or decomposed after processing, such as drying (Angiolillo et al. 2015; Altemimi et al. 2017). In this study, the influence of sundrying and oven-drying treatment on the metabolite profile of $R$. apiculata leaves was observed. The result of phytochemical comparison is shown in Table 1 .

The result of phytochemical test indicates that all crude extracts gave positive results for alkaloid, flavonoid, saponin, and steroid/triterpenoid. Nonetheless, previous studies reported various results of this qualitative test. Poompozhil and Kumarasamy (2014) dried R. apiculata leaves by shade-dried method at room temperature then extracted using methanol showed positive results for alkaloids, flavonoids, phenols, saponins, steroids, and terpenoids. A similar result was reported by Muthulingam and Chaithanya (2018). The shade-dried $R$. apiculata leaves gave positive results on phenolic, alkaloid, flavonoids, tannin, saponin but it did not show positive results of steroids. Nevertheless, a recent study stated that the shade-dried methanol extract of the leaves contained alkaloid, flavonoid, phenol hydroquinone, tannin, and saponin, whereas the extract gave negative results for triterpenoid and steroid (Mulyani et al. 2019). The various results of phytochemical content of $R$. apiculata might be caused by the different production of secondary metabolites by this plant. As noted, plant produces secondary metabolites to adapt to environmental stress such as salinity, $\mathrm{pH}$, light uptake, moisture, drought, tide and nutrient uptake from the soil (Dasgupta et al. 2014; Iwuala and Alam 2017; Uddin 2019). The presence of steroid/triterpenoid content in our crude extracts was suggested as the response of salinity fluctuation in its habitat, even less our samples were taken from the tree which grew in the tidal area. The salinity fluctuation in the sampling location was reported by Ariyanto et al. (2018). They stated that the lowest salinity that recorded was $16.67 \pm 2.87$ psu (practical salinity unit), while the highest salinity was $34.46 \pm 0.78 \mathrm{psu}$. This contention is supported by Basyuni et al. $(2009,2012)$ who stated mangrove produces triterpenoid derivatives to tolerate the salinity fluctuation in the environment. Moreover, steroid derivatives such as brassinosteroid, known as plant hormone, also play an important role in salt tolerance, development, and growth (Ryu and Cho 2015; Su et al. 2019). Further analysis to understand the effect of drying treatment on the metabolite by thin-layer chromatography (TLC) is shown in Figure 2.

Metabolite profiling through TLC led to a fact that the pre-drying treatment gave chemical alteration in the $R$. apiculata leaves (Figure 2). Crude extracts of fresh and oven-dried leaves were noted to have 10 spots on the TLC plates after visualization, on the other hand, the sun-dried leaves merely gave 9 spots because it lacked one spot at $R_{\mathrm{f}}$ value of 0.61 (Table 2). This might have happened because the missing spot contained unstable or photolabile compounds. Consequently, the compounds were degraded and subsided, or the amount was decreased by the exposure to sunlight during the drying. Ademiluyi et al. (2018) 
showed that sun-drying method for plant leaves causing a significant reduction of certain metabolite contents such as alkaloid, flavonoid, saponin, oxalate and vitamin C. Interestingly, most of studies stated that oven-drying treatment resulted in higher amount of beneficial bioactive substances such as flavonoid, tannin, and phenolic rather than the sun-drying (Roshanak et al. 2016; Mbondo et al. 2018). Furthermore, the chemical alteration after the drying treatment also could be detected using HPLC which is presented in Figure 3.

The application of HPLC-DAD for observing the effect of drying treatment on metabolite profile of $R$. apiculata leaves was performed according to the report by Ademiluyi et al. (2018) which showed HPLC-DAD has decent sensitivity to compare metabolite profiles in particular samples with or without any marker standard in several UV-wavelengths. Chemical alteration was not detected by UV monitoring at 210 and $254 \mathrm{~nm}$, whereas UV monitoring at $400 \mathrm{~nm}$ successfully showed chemical alteration at retention times $\left(R_{\mathrm{t}}\right) 29$ to 30 mins caused during drying process. The retention time $\left(R_{\mathrm{t}}\right)$ of the altered peaks is shown in Table 3.

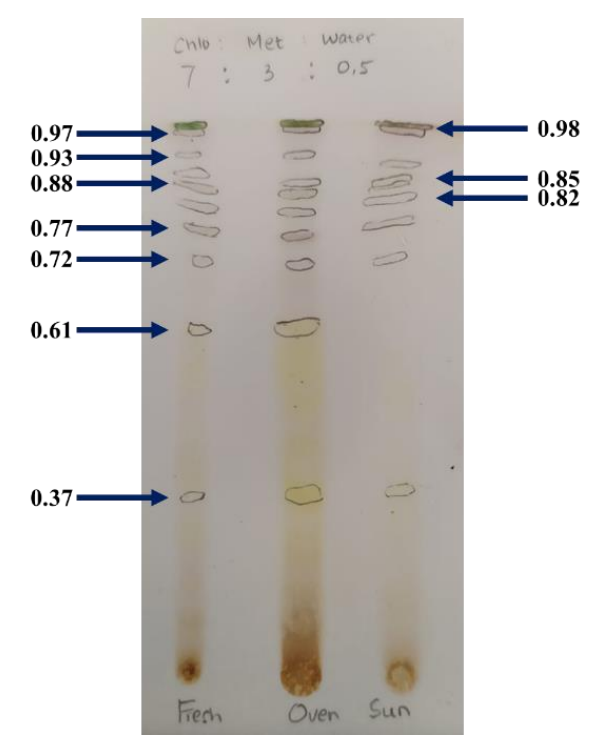

Figure 2. TLC chromatogram of $R$. apiculata leaves crude extracts in different treatments after spraying $5 \%$ sulfuric acid in 1-butanol

Table 1. Phytochemical content in fresh, oven-dried and sun-dried R. apiculata leaves

\begin{tabular}{|c|c|c|c|c|}
\hline $\begin{array}{c}\text { Phytochemical } \\
\text { test }\end{array}$ & Positive result & Fresh & Oven-dried & Sun-dried \\
\hline Alkaloid & $\begin{array}{l}\text { Presence of yellow to deep } \\
\text { orange precipitate }^{1}\end{array}$ & +++ & + & ++ \\
\hline Flavonoid & $\begin{array}{l}\text { Presence of yellow to } \\
\text { orange color after addition } \\
\text { of } 1 \% \mathrm{KOH}^{2}\end{array}$ & + & + & +++ \\
\hline Saponin & $\begin{array}{l}\text { Formation of a stable foam } \\
\text { after addition of } 2 \mathrm{~N} \mathrm{HCl}^{1}\end{array}$ & + & +++ & + \\
\hline Steroid/ & Formation of green color in & +++ & +++ & +++ \\
\hline Triterpenoid & $\begin{array}{l}\text { the upper layer and deep red } \\
\text { to color in the lower layer }{ }^{1}\end{array}$ & $\begin{array}{l}\text { Perolk } \\
\text { Presh }\end{array}$ & $\begin{array}{l}\text { Steroid } \\
\text { Oven }\end{array}$ & sun \\
\hline
\end{tabular}

Note: +: positive;-: negative. The more “+" notation indicates more convincing result. ${ }^{1}$ according to Sibero et al. (2019); ${ }^{2}$ according to Khan et al. (2011) 
Table 2. Retention factor $\left(R_{\mathrm{f}}\right)$ of TLC spots from $R$. apiculata leaves crude extracts

\begin{tabular}{|c|c|c|c|c|c|c|c|c|c|c|}
\hline \multirow{2}{*}{ Treatment } & \multicolumn{10}{|c|}{ Retention factors $\left(\boldsymbol{R}_{\mathrm{f}}\right)$} \\
\hline & 0.98 & 0.97 & 0.93 & $\mathbf{0 . 8 8}$ & 0.85 & 0.82 & 0.77 & $\mathbf{0 . 7 2}$ & 0.61 & 0.37 \\
\hline Fresh & $\bullet$ & • & - & - & $\bullet$ & $\bullet$ & $\bullet$ & $\bullet$ & $\bullet$ & - \\
\hline Oven-dried & - & - & - & - & - & - & - & - & - & - \\
\hline Sun-dried & - & - & - & - & - & - & - & - & $x$ & - \\
\hline Color & Intense green & Pale purple & Pale yellow & Pale yellow & Pale purple & Grey & Grey & Pale yellow & Yellow & Yellow \\
\hline
\end{tabular}

Note: "•" indicates the presence of the same $R_{\mathrm{f}}$; while notation “×” indicates the absence of the same $R_{\mathrm{f}}$ in the crude extract)
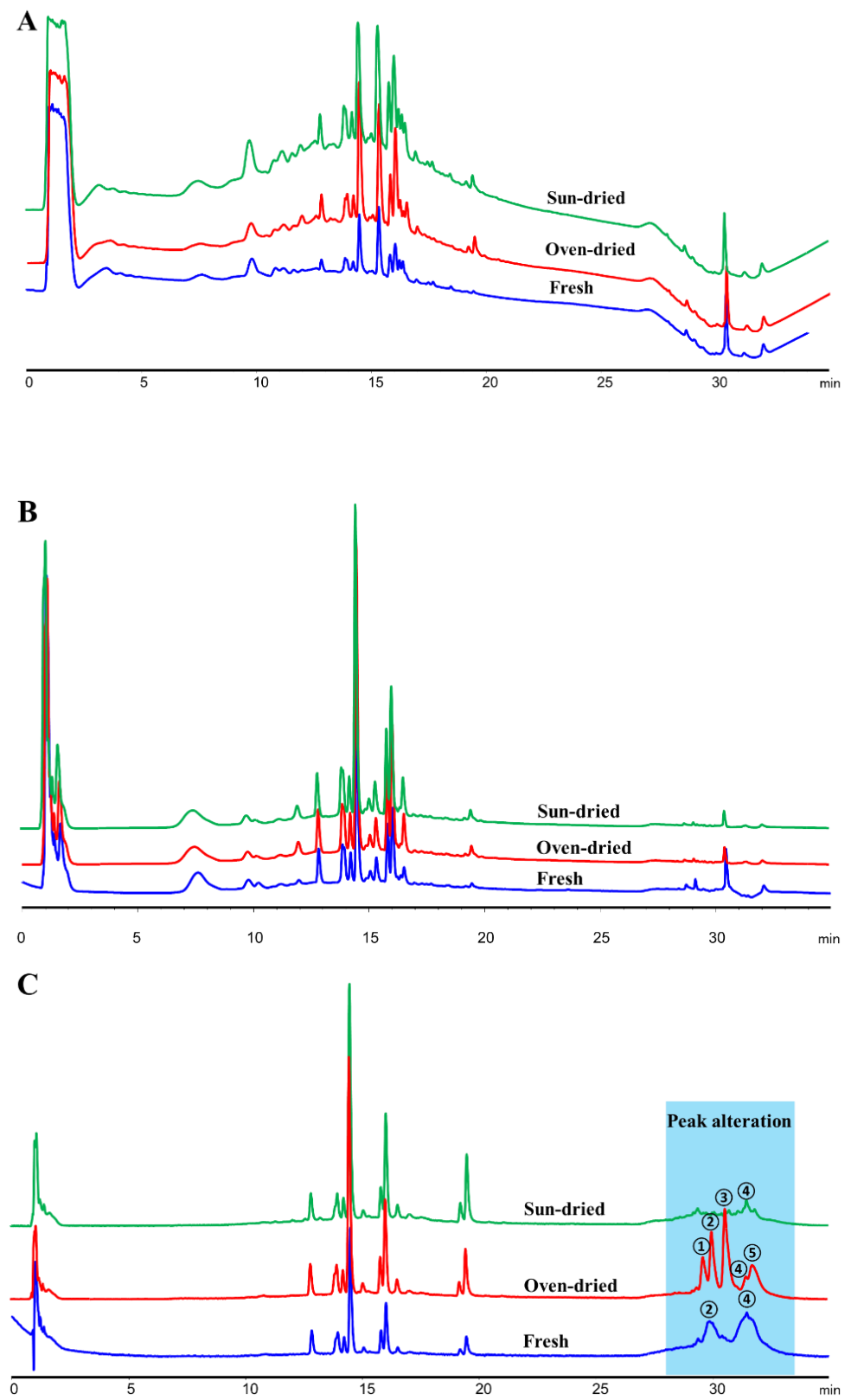

Figure 3. HPLC chromatogram of fresh (blue), oven-dried (red) and sun-dried (green) R. apiculata crude extracts. HPLC chromatograms were recorded at $210 \mathrm{~nm}$ (A), $254 \mathrm{~nm}$ (B) and $400 \mathrm{~nm}$ (C) 

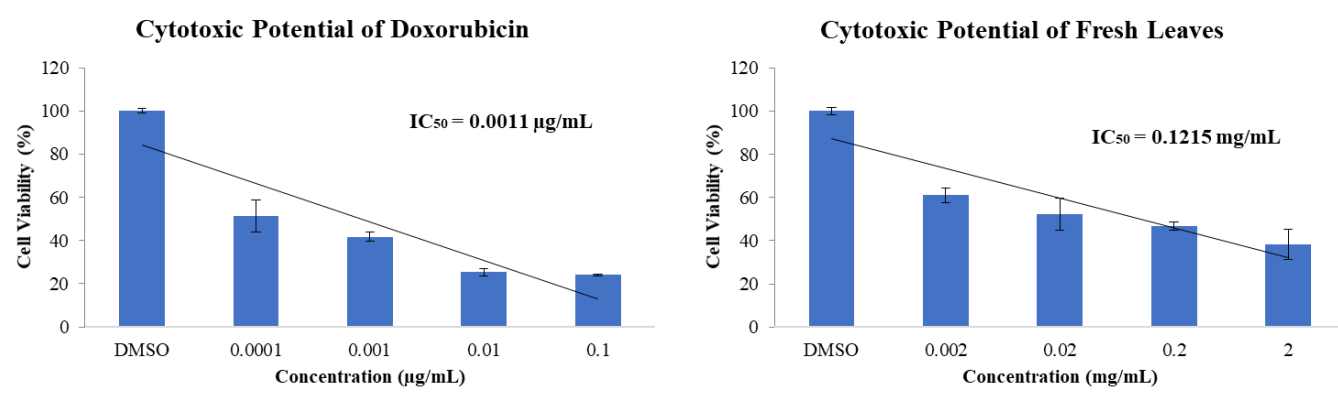

Cytotoxic Potential of Sun-Dried Leaves

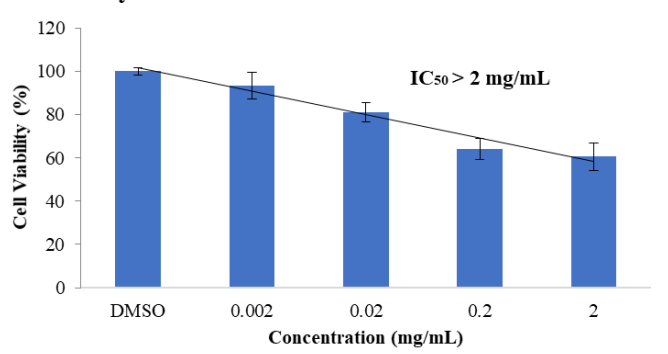

Cytotoxic Potential of Oven-Dried Leaves

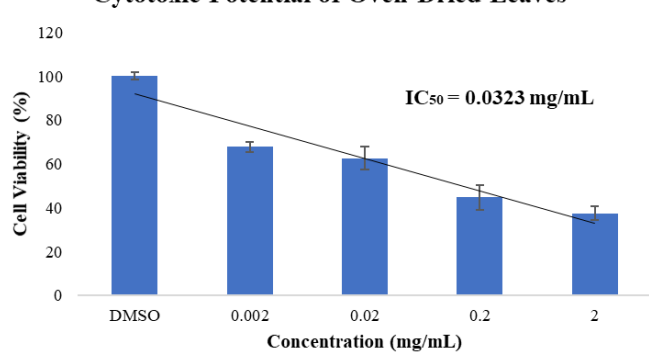

Figure 4. $\mathrm{IC}_{50}$ value of Doxorubicin and crude extracts of $R$. apiculata leaves against P388 murine leukemia cells

Table 3. Retention time $\left(R_{\mathrm{t}}\right)$ of altered peaks in the R. apiculata leaves extracts which detected at $400 \mathrm{~nm}$

\begin{tabular}{|c|c|c|c|c|c|}
\hline \multirow{2}{*}{ Samples } & \multicolumn{5}{|c|}{ Retention time $\left(R_{t}\right)(\min )$} \\
\hline & 1 & 2 & 3 & 4 & 5 \\
\hline Fresh & - & 29.8 & - & 31.4 & - \\
\hline Oven-dried & 29.6 & 30.0 & 30.6 & 31.5 & 31.7 \\
\hline Sun-dried & - & - & - & 31.4 & - \\
\hline
\end{tabular}

Note: Peaks were detected by UV lamp at $400 \mathrm{~nm}$

Compounds detected by UV absorption at $400 \mathrm{~nm}$ are usually contained chromophore that gives color to the compounds. This compound type is usually easily degraded by unfavorable environmental condition such as heat and light. Peak number 4 which detected by UV lamp at 400 $\mathrm{nm}$ in fresh $\left(R_{\mathrm{t}}\right.$ value of $\left.31.4 \mathrm{~min}\right)$, oven-dried $\left(R_{\mathrm{t}}\right.$ value of $31.5 \mathrm{~min})$, and sun-dried $\left(R_{\mathrm{t}}\right.$ value of $\left.31.4 \mathrm{~min}\right)$ crude extracts is suggested as thermo and photo-stable compounds. These compounds are not degraded by exposure to sunlight and heat during the drying. Then, peak number 2 appeared at fresh and oven-dried chromatogram suggested to be the thermo-stable but photolabile. Interestingly, two peaks (numbers 3 and 5) appeared merely in oven-dried crude extract at $R_{\mathrm{t}}$ value of $30.6 \mathrm{~min}$ and $31.7 \mathrm{~min}$. Roshanak et al. (2016) stated that drying treatment will inactivate certain enzyme that probably causes degradation of metabolites in the plant. The dry samples did not have sufficient water to activate the enzyme, thereby limiting, the degradation of metabolite (Mediani et al. 2014). This explanation rationalizes the previous studies which reported higher phenolic content in dried samples than the fresh sample. Hence, the peak numbers 3 and 5 were suggested as the thermo-stable compounds. However, these compounds were either photolabile or were prone to degradation by particular endogenous enzymes in fresh extracts.

The effect of drying treatment to cytotoxic property of $R$. apiculata leaves and Doxorubicin are presented in Figure 4. The results of cytotoxicity assay show that the highest toxicity ( $\mathrm{IC}_{50}$ value of $0.0323 \mathrm{mg} / \mathrm{mL}$ ) was observed in extracts of oven-dried leaves, followed by that of fresh leaves ( $\mathrm{IC}_{50}$ value of $0.1215 \mathrm{mg} / \mathrm{mL}$ ). In contrast, the sun-dried leaves had lowest cytotoxicity $\left(\mathrm{IC}_{50}\right.$ value of $>2 \mathrm{mg} / \mathrm{mL}$ ) whereas Doxorubicin as the positive control had IC50 value of $0.0011 \mu \mathrm{g} / \mathrm{mL}$. It is highlighted that the oven-drying treatment gave the best $\mathrm{IC}_{50}$ value, while the sun-drying treatment weakened the cytotoxicity against P388 murine leukemia cells. Interestingly, the weakening of bioactivity in sun-drying might be correlated to the loss of several metabolites which emphasized by Figure 3 and Table 3. Hence, it is expected that the lost metabolites might play important role in the anticancer activity of $R$. apiculata leaves.

As a summary, this study showed that drying treatment caused alteration of metabolite profile in the $R$. apiculata leaves. TLC and HPLC analyses explained that oven drying caused the disappearance of heat-intolerant compounds, while the heat and light-sensitive compounds were disappeared in the sun-drying crude extract. However, 
the result of the phytochemical test indicated that there was no difference in bioactive compounds in fresh and dried leaves, qualitatively. Furthermore, this study showed that oven-drying treatment can preserve the anticancer potential of $R$. apiculata leaves.

\section{ACKNOWLEDGEMENTS}

We thank Biotechnology Research Center, Toyama Prefectural University, Japan which provided reagents and instruments to conduct all analyses for this study. This article is an outcome of research grant from the Faculty of Fisheries and Marine Science, Universitas Diponegoro, Indonesia scheme 2020, and fellowship program funded by Toyama Prefectural University to MTS.

\section{REFERENCES}

Ademiluyi AO, Aladeselu OH, Oboh G, Boligon G. 2018. Drying alters the phenolic constituents, antioxidant properties, $\alpha$-amylase, and $\alpha$ glucosidase inhibitory properties of Moringa (Moringa oleifera) leaf. Food Sci Nutr 6 (8): 2123-33. DOI: 10.1002/fsn3.770.

Aljaghthmi O, Heba H, Zeid IA. 2018. Bioactive compounds extracted from mangrove plants (Avicennia marina and Rhizophora mucronata): an overview. Pathophysiology. DOI: 10.1016/j.pathophys.2018.09.002.

Altemimi A, Lakhssassi N, Baharlouei A, Watson DG, and Lightfoot DA. 2017. Phytochemicals: extraction, isolation, and identification of bioactive compounds from plant extracts. Plants 6 (4). DOI: 10.3390/plants6040042.

Angiolillo L, Nobile MAD, Conte A. 2015. The extraction of bioactive compounds from food residues using microwaves. Curr Opin Food Sci 5: 93-98. DOI: 10.1016/j.cofs.2015.10.001.

Ariyanto D, Bengen DG, Prartono T, and Wardiatno Y. 2018. The association of Cassidula nucleus (Gmelin 1791) and Cassidula angulifera (petit 1841) with mangrove in Banggi coast, Central Java, Indonesia. AACL Bioflux 11 (2): 348-61.

Basyuni M, Baba S, Inafuku M, Iwasaki H, Kinjo K, Oku H. 2009. Expression of terpenoid synthase MRNA and terpenoid content in salt-stressed mangrove. J Plant Physiol 166 (16): 1786-1800. DOI: 10.1016/j.jplph.2009.05.008.

Basyuni M, Baba S, Kinjo Y, Putri LAP, Hakim L, and Oku H. 2012. Salt-dependent increase in triterpenoids is reversible upon transfer to freshwater in mangrove plants Kandelia candel and Bruguiera gymnorrhiza. J Plant Physiol 169 (18): 1903-1908. DOI: 10.1016/j.jplph.2012.08.005.

Bibi SN, Fawzi MM, Gokhan Z, Rajesh J, Nadeem N, Kannan RRR, Albuquerque RDDG, Pandian SK. 2019. Ethnopharmacology, phytochemistry, and global distribution of mangroves-A comprehensive review. Mar Drugs 17 (4). DOI: 10.3390/md17040231.

Darajati, Wahyuningsih, Pratiwi S, Herwinda E, Radiansyah AD, Nalang VS, Nooryanto B, Rahajoe SJ, et al. 2016. Indonesian Biodiversity Strategy and Action Plan 2015-2020. Kementerian Perencanaan Pembangunan Nasional/BAPPENAS, Jakarta. [Indonesian]

Dasgupta N, Sengupta C, Das S. 2014. Role of secondary metabolites and radical scavenging aptitude for better adaptability of mangroves in varying salinity of Sundarbans, India. Ann Trop Res 22: 1-22. DOI: 10.32945/atr3621.2014.

Dewanjee S, Gangopadhyay M, Bhattacharya N, Khanra R, and Dua TK 2015. Bioautography and its scope in the field of natural product chemistry. J Pharm Anal 5 (2): 75-84. 10.1016/j.jpha.2014.06.002.

Diastuti H, Warsinah. 2010. The anticancer compound identification from chloroform extract of Rhizophora mucronata stem bark. Indo J Pharm 21 (4): 279-84.

FAO. 2005. Global Forest Resources Assessment 2005 Thematic Study on Mangroves Indonesia. Forestry Department Food and Agriculture Organization of the United Nations, Rome.
Guaadaoui A, Benaicha S, Elmajdoub N, Bellaoui M, Hamal A. 2014. What is a bioactive compound? A combined definition for a preliminary consensus. Int J Food Sci Nutr 3 (3): 17-179. DOI: 10.11648/j.ijnfs.20140303.16.

Iwuala EN, Alam A. 2017. Effects of simulated drought stress on secondary metabolite production in red mangrove (Rhizophora mangle L.; Rhizophoraceae). J Adv Biol Biotech 15 (1): 1-6. DOI: 10.9734/jabb/2017/36300.

Joel EL, Bhimba, V. 2010. Isolation and characterization of secondary metabolites from the mangrove plant Rhizophora mucronata. Asian Pac J Trop Biomed 3 (8): 602-604. DOI: 10.1016/S19957645(10)60146-0.

Khan AM, Qureshi RA, Ullah F, Gilani SA, Nosheen A, Sahreen S, Laghari MK, Rehman SU, Hussain I, Murad W. 2011. Phytochemical analysis of selected medicinal plants of Margalla hills and surroundings. J Med Plant Res 5 (25): 6017-23. DOI: 10.5897/JMPR11.869.

Kusmana C. 2018. Mangrove plant utilization by local coastal community in Indonesia. IOP Conf Ser: EES 196 (1). DOI: 10.1088/17551315/196/1/012028.

Mbondo NN, Owino WO, Ambuko J, and Sila DN. 2018. Effect of drying methods on the retention of bioactive compounds in African eggplant. Food Sci Nutr 6 (4): 814-23. DOI: 10.1002/fsn3.623

Mediani A, Abas F, Tan CP, and Khatib A. 2014. Effects of different drying methods and storage time on free radical scavenging activity and total phenolic content of Cosmos caudatus. Antioxidants 3 (2): 358-70. DOI: 10.3390/antiox3020358

Mulyani Y, Syaputra ND, Dewi KC, Lili W, and Agung MUK. 2019. Total phenolic, flavonoid content and antioxidant capacity of stem bark, root, and leaves methanolic extract of Rhizophora mucronata Lam. World News Nat Sci 26: 118-27.

Muthulingam M, Chaithanya KK. 2018. Qualitative and quantitative phytochemical analysis and in vitro antioxidant activities of methanolic leaf extract of Rhizophora apiculata Blume. Drug Invent. Today 10(3): 3335-3343.

Palaniyandi T, Sivaji A, Thiruganasambandam R, Natarajan S, Hari R. 2018. In vitro anti gastric cancer activity of squalene, a terpenoid compound isolated from Rhizophora mucronata mangrove plant leaves against AGS Cell Lone. Pharmacogn Mag 14 (57): 369-76. https://doi.org/10.4103/pm.pm.

Poompozhil S, Kumarasamy D. 2014. Studies on phytochemical constituents of some selected mangroves. JAIR 2(10): 590-593.

Pringgenies D, Yudiati E, Nuraini RAT, Susilo ES, and Rahayuningsih E. 2018. Optimal concentration of mangrove (Rhizophora mucronata) leaf and propagule based natural dye. Mal J Fund Appl Sci 14 (1-2): $168-73$

Purwanti R. 2016. Studi etnobotani pemanfaatan jenis-jenis mangrove sebagai tumbuhan obat di Sulawesi. Proceeding of Mulawarman Pharmaceuticals Conferences, 3 (2), 340-348. Samarinda, 20-21 April 2016. [Indonesian]

Ramalingam V, Rajaram R. 2018. Enhanced antimicrobial, antioxidant, and anticancer activity of Rhizophora apiculata: An experimental report. 3 Biotech 8(200). DOI: https://doi.org/10.1007/s13205-0181222-2

Roshanak S, Rahimmalek M, and Goli SAH. 2016. Evaluation of seven different drying treatments with respect to total flavonoid, phenolic, vitamin $\mathrm{C}$ content, chlorophyll, antioxidant activity, and color of green tea (Camellia sinensis or C. assamica) leaves. J Food Sci Tech 53 (1): 721-29. DOI: 10.1007/s13197-015-2030-x

Ryu H, Cho YG. 2015. Plant hormones in salt stress tolerance. J Plant Biol 58 (3): 147-55. DOI: 10.1007/s12374-015-0103-Z

Saranraj P, Sujitha D. 2015. Mangrove medicinal plants: A review. Am$\begin{array}{lllll}\text { Eurasian J Toxicol Sci } 7 \text { (3): 146-156. DOI: } & \end{array}$ 10.5829/idosi.aejts.2015.7.3.94150.

Saranya A, Ramanathan T, Kesavanarayanan KS, Adam A. 2015. Traditional medicinal uses, chemical constituents and biological activities of a mangrove plant, Acanthus ilicifolius Linn.: A brief review. Am-Eurasian J Agric Environ Sci 15 (2): 243-250. DOI: 10.5829/idosi.aejaes.2015.15.2.12529.

Seepana R, Perumal K, Kada NM, Chatragadda R, Raju M, Annamalai V. 2016. Evaluation of antimicrobial properties from the mangrove Rhizophora apiculata and Bruguiera gymnorrhiza of Burmanallah coast, South Andaman, India. J Coast Life Med. 4 (6): 475-478. DOI: 10.12980/jclm.4.2016J6-52 
Sharma AR, Zhou T, Harunari E, Oku N, Trianto A, and Igarashi Y. 2019. Labrenzbactin from a coral-associated bacterium Labrenzia sp. J Antibiot 72 (8): 634-639. DOI: 10.1038/s41429-019-0192-x.

Sibero MT, Igarashi Y, Radjasa OK, Sabdono A, Trianto A, Zilda DS, Wijaya YJ. 2019. Sponge-associated fungi from a mangrove habitat in Indonesia: Species composition, antimicrobial activity, enzyme screening and bioactive profiling. Intl Aquat Res 11 (2): 173-86. DOI 10.1007/s40071-019-0227-8.

Su W, Ye C, Zhang Y, Hao S, Li QQ. 2019. Identification of putative key genes for coastal environments and cold adaptation in mangrove Kandelia obovata through transcriptome analysis. Sci Tot Environ 681: 191-201. DOI: 10.1016/j.scitotenv.2019.05.127.
Sumardi, Basyuni M, Wati R. 2018. Antimicrobial activity of polyisoprenoids of sixteen mangrove species from North Sumatra, Indonesia. Biodiversitas 19 (4): 1243-1248. DOI: 10.13057/biodiv/d190409.

Tarman K, Purwaningsih S, Negara AAPAP. 2013. Aktivitas antibakteri ekstrak daun bakau hitam (Rhizophora mucronata) terhadap bakteri penyebab diare. Jurnal Pengolahan Hasil Perikanan Indonesia 16 (3): 249-58. [Indonesian]

Uddin M. 2019. Environmental factors on secondary metabolism of medical plants. Acta Scientific Pharmaceutical Sciences 3 (8): 34-46. DOI: 10.31080/ASPS.2019.03.0338. 